\title{
Hemophagocytic Syndrome; A Mortal Progressing Case Despite Early Diagnosis and Treatment
}

\section{Hemofagositik Sendrom; Erken Teşhis ve Tedaviye Rağmen Ölümcül İlerleyen Bir Vaka}

\author{
Deniz İncaman', @Musa Salmanoğlu², ๑Abdulbaki Kumbasar ${ }^{3}, \oplus O ̈ m u ̈ r ~ T a b a k{ }^{4}$ \\ 'Kastamonu Training Hospital, Department of Internal Medicine, Kastamonu, Turkey \\ 2SBU Sultan Abdulhamit Han Haydarpasa Training Hospital, Department of Internal Medicine, İstanbul, Turkey \\ ${ }^{3}$ SBU Bakırköy Sadi Konuk Training Hospital, Department of Internal Medicine, İstanbul, Turkey \\ ${ }^{4}$ SBU Kanuni Sultan Süleyman Training Hospital, Department of Internal Medicine, İstanbul, Turkey
}

\begin{abstract}
In this case, we discussed with a hemaphagocytic syndrome in a patient who was investigated for jaundice. Hemophagocytic syndrome; fever, hypertriglyceridemia, hepatosplenomegaly, bone marrow involvement is a multisystemic disease. This is due to excess cytokines released from the cells. Hemophagocytic syndrome, can occur as a familial or sporadic disorder, and it can be triggered by a variety of events that disrupt immune homeostasis.
\end{abstract}

Keywords: Hemophagocytic syndrome, jaundice, pancytopenia

\section{INTRODUCTION}

Hemophagocytic syndrome is in the group associated with macrophages within the histocytosis group of diseases. HLH does not constitute a single disease, but a picture of different conditions that produce the same type of inflammatory response. In this article, we will talk about the methods followed for diagnosis and a case that was mortal despite treatment.

\section{CASE}

A 51-year-old male patient with a history of known hypertension and coronary artery disease was admitted to the emergency department of our hospital with the complaint of jaundice that started 5 days ago. The patient
Öz

Bu vakada, sarılık sebebiyle araştırılan bir hastada hemafagositik sendromu tartıştık. Hemofagositik sendrom; ateş, hipertrigliseridemi, hepatosplenomegali, kemik iliği tutulumu olan multisistemik bir hastalıktır. Bunun nedeni hücrelerden aşırı salınan sitokinlerdir Hemofagositik sendrom, ailesel veya sporadik bir bozukluk olarak ortaya çıkabilir ve bağışıklık homeostazını bozan çeşitli olaylar tarafından tetiklenebilir.

Anahtar Kelimeler: Hemofagositik sendrom, sarılık, pansitopeni

had no history of drug use other than acetylsalicytic acid $1 \times 100 \mathrm{mg}$ and ramipril $1 \times 5 \mathrm{mg}$. In the questioning made with suspicion of intoxication, the patient stated that he did not use mushrooms, herbal tea, drugs, cannabis. Physical examination revealed body temperature 39.2 degrees, blood pressure 100/60 mmhg, pulse 120/min, icteric appearance and hepatosplenomegaly.

\section{Table 1. Laboratory parameters and normal ranges}

$\begin{array}{lccc}\text { WBC } & 4,000-11,00010 \mathrm{e}^{3} / \mathrm{dL} & \text { AST/ALT } & 0-30 \mathrm{U} / \mathrm{L} \\ \mathrm{Hb} & 11-15 \mathrm{~g} / \mathrm{dL} & \text { GGT } & 70-120 \mathrm{U} / \mathrm{L} \\ \text { PLT } & 150-45010 \mathrm{e}^{3} / \mathrm{dL} & \text { ALP } & 30-120 \mathrm{U} / \mathrm{L} \\ \text { Urea } & 8-21 \mathrm{mg} / \mathrm{dL} & \text { ferritin } & 2-400 \mathrm{ng} / \mathrm{mL} \\ \text { Creatinin } & 0.3-1.1 \mathrm{mg} / \mathrm{dL} & \text { LDH } & 0-250 \mathrm{U} / \mathrm{L} \\ \text { CRP } & 0.5-6 \mathrm{mg} / \mathrm{dL} & \text { Total Bilirubin } & 0.3-1.2 \mathrm{mg} / \mathrm{dL} \\ \text { Fibrinojen } & 180-400 \mathrm{mg} / \mathrm{dL} & \text { Triglyceride } & 50-150 \mathrm{mg} / \mathrm{dL}\end{array}$


White blood cells (WBC) in examinations; $800010 \mathrm{e}^{3} /$ $\mathrm{dL}$, Hemoglobin $(\mathrm{Hb}) ; 9 \mathrm{mg} / \mathrm{dL}$, platelet $(\mathrm{PLT}) ; 102.000$ $10 \mathrm{e}^{3} / \mathrm{dL}$, urea; $52 \mathrm{mg} / \mathrm{dL}$, creatinine, $0.9 \mathrm{mg} / \mathrm{dL}$, aspartate aminotransferases (AST); $213 \mathrm{U} / \mathrm{L}$, alanine aminotransferases (ALT); $178 \mathrm{U} / \mathrm{L}$, gamma-glutamyl transpeptidase (GGT); $74 \mathrm{U} / \mathrm{L}$, alkaline phosphatase (ALP); $96 \mathrm{U} / \mathrm{L}$, lactate dehydrogenase (LDH); $479 \mathrm{U} / \mathrm{L}$, total bilirubin; $20.4 \mathrm{mg} / \mathrm{dL}$, direct bilirubin; $18.7 \mathrm{mg} / \mathrm{dL}, \mathrm{CRP}$; It was found to be $9 \mathrm{mg} / \mathrm{dL}$. In all abdominal ultrasonography; hepatosteatosis and hepatosplenomegaly were observed. Toxication analysis sent in urine and serum viral markers (Anti-CMV IgM, EBV-VCA IgM, EBNA IgM, AntiHIV, Anti-HAV, HBsAg, Anti-HbS, Anti-Hbc IgM, Anti-HBC, rubella, parvovirus B- 19, HSV-1-2, influenza, adenovirus), rose bengal and tuberculin skin test negative, ferritin 13000 $\mathrm{ng} / \mathrm{mL}$, triglyceride $380 \mathrm{mg} / \mathrm{dl}$, fibrinogen resulted in $50 \mathrm{mg} /$ dL. Pancytopenia was observed in the examined peripheral blood smear, no atypical cells were seen. It was reported that the liver and spleen were increased in size and the appearance was compatible with hepatitis in dynamic MRI imaging of the whole abdomen. Cholestatic causes were excluded due to the absence of obstructive lesions in intra-extra hepatic bile ducts Contrasted cranial MRI imaging was performed when the patient complained of headache, no feature was observed. Neurology was interviewed for puncture (LP) indication. However, tension-type headache was considered because the patient had a short-term headache, no pathology in the neurological examination, and normal cranial examination. LP was not indicated. Liver biopsy was performed from the patient for the etiology of hyperbilirubinemia. Bone marrow biopsy was performed to elucidate the etiology of cytopenia. Intense inflammatory cells and hemophagocytic cells were observed in the aspiration (Figure 1). The patient also had fever, bicytopenia, hepatosplenomegaly, high ferritin level, hypertriglyceridemia, hypertriglyceridemia. After the diagnosis was made (Table 2 ), dexamethasone $10 \mathrm{mg}$ $1 \times 1$ treatment was initiated and his etiology investigation continued.

Stool direct examination, culture, clostridium difficile, helicobacter pylori tests were negative. In the complete urinalysis, +3 bilirubin and legionella antigen in urine were negative. The direct examination of the sputum sent was normal, there was no growth in the culture, and infectious causes were excluded when the sputum sent three times was negative for ARB. The sent autoimmune markers (ANA, Anti-ds DNA, Anti LKM antigen, ASMA, AMA) were negative. Since primary hemophagocytic syndrome can be seen rarely in adults, a genetic examination was sent, but no abnormal gene mutation was found. Secondary etiology was continued to be investigated.No pathological finding was determined. Gastroscopy revealed erythematous gastritis, and the colonoscopy was normal. The patient underwent PET-CT, diffuse FDG uptake in the liver and spleen (SUV. max 7.0), bilateral inguinal LAP of $20 \mathrm{~mm}$ (SUV.max 2.4), the largest number of $36 \mathrm{~mm}$ LAP in the abdomen and pelvic region (SUV. Lymph node biopsy was planned. As a result of
Table 2. Hemophagocytic syndrome-2004 diagnostic criteria ${ }^{[7]}$

The diagnosis of HLH may be established:

A. Molecular diagnosis consistent with HLH: pathologic mutations of PRF1, UNC13D, Munc18-2, Rab27a, STX11, SH2D1A, or BIRC4

B. Five of the 8 criteria listed below are fulfilled:

1. Fever $>38.5^{\circ} \mathrm{C}$

2. Splenomegaly

3. Cytopenias (affecting at least 2 of 3 lineages in the peripheral blood) Hemoglobin $<9 \mathrm{~g} / \mathrm{dL}$ (in infants 4 weeks: hemoglobin $10 \mathrm{~g} / \mathrm{dL}$ ) Platelets $100 \times 10^{3} / \mathrm{mL}$ Neutrophils $<1 \times 10^{3} / \mathrm{mL}$

4. Hypertriglyceridemia (fasting, $265 \mathrm{mg} / \mathrm{dL}$ ) and/or hypofibrinogenemia $(<150 \mathrm{mg} / \mathrm{dL})$

5. Hemophagocytosis in bone marrow, spleen, lymph nodes, or liver

6 . Low or absent NK-cell activity

7. Ferritin $>500 \mathrm{ng} / \mathrm{mL}$

8. Elevated sCD25 (alfa-chain of sIL-2 receptor)

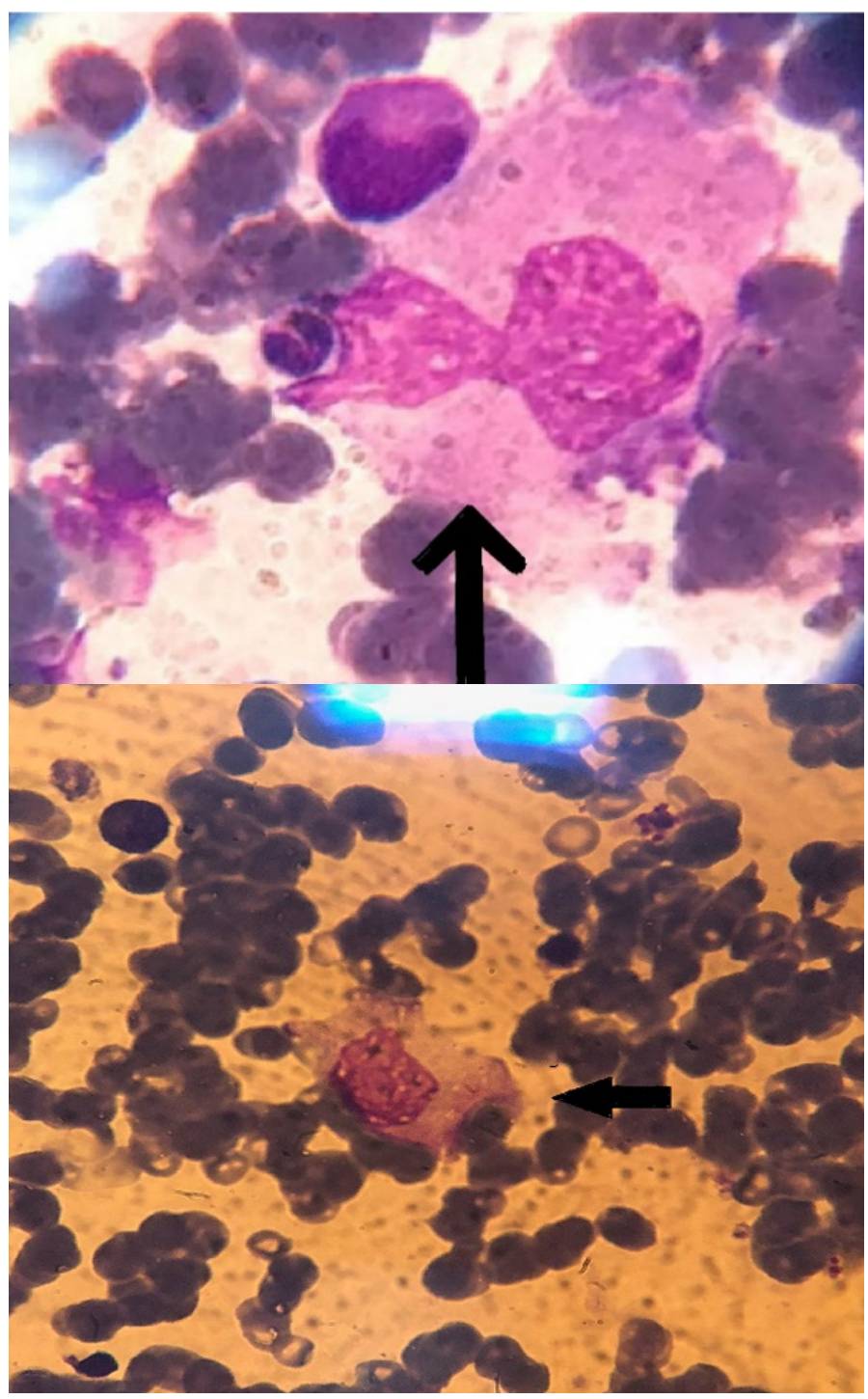

Figure 1. Bone marrow aspiration image, showing phagocytosing hemophagocytic cell (H.E x100, x400)

liver biopsy and bone marrow biopsy, hemophagocytic cells and dense inflammatory cells were reported in accordance with the diagnosis of hemophagocytic syndrome. Edema and neutropenia developed during follow-up. The etiology could not be clarified, the patient was given intravenous 
immunoglobulin for 3 days when there was no response to dexamethasone. During the follow-up, the patient had persistent fever. No growth in blood, urine, and sputum cultures taken when the patient was admitted and when he had a fever, CRP did not increase procalcitonin, it was considered as malign fever. $10 \mathrm{~kg}$ loss was detected. The patient's ferritin level reached $21000 \mathrm{ng} / \mathrm{mL}$, total bilirubin $25 \mathrm{mg} / \mathrm{dL}$, and WBC $32 \times 10^{3} / \mathrm{uL}$. The patient whose general condition deteriorated within days was lost.

\section{DISCUSSION}

Hemophagocytic syndrome, also known as hemophagocytic lymphohistiocytosis (HLH), is in the group of diseases related to macrophages in the group of diseases in the histiocytosis group. and a clinical picture with predominant cytopenia. [1] Hemophagocytic syndrome usually occurs in the course of hematological malignancies, primary or secondary immunodeficiency, autoimmune diseases, viral, bacterial or parasitic infections. Both primary and secondary HFS can be triggered by infections or other autoimmune events. In practice, the distinction between primary or secondary is not important in the management of the disease. ${ }^{[2,3]}$ Primary HFS can be seen in the course of genetic and immunosuppressed diseases. Chediak-Higashi syndrome 1 (CHS 1), Griscelli syndrome 2 (GS 2), X linked lymphoproliferative syndrome, Hermanski-Pudlak syndrome, lysinuric proteinuria. Genetic ones are seen in newborn babies, the ratio of female to male is $1: 1$ and males are more prone in adults. PRF1, UNC13D, STX11 mutations are seen with a high rate in individuals of Turkish origin. ${ }^{[4]}$ Infection-related hemophagocytic syndrome can be caused by endogenous products (tissue damage, metabolic products, radical stress), rheumatic diseases, macrophage activation syndrome, and malignant diseases. ${ }^{[5]}$ HFS is not a type of cancer, it occurs as a result of destruction in tissues as a result of abnormal immune activation and excessive inflammation. Interferongamma, tumor necrosis factor-alpha, interleukin-2, IL-6, IL-10, IL-12 are found to be high. Hematopoietic cells phagocyted by macrophages can often be demonstrated histologically in bone marrow, lymph nodes, liver and spleen. Although they are cytologically benign in all organs, they can be infiltrated by lymphohistiocytic cells showing active phagocytosis. ${ }^{[2]}$ The most common detecting infectious agent for HFS is EbsteinBarr virus (EBV). In one study, the organism that triggered HFS was detected in 163 of 219 HFS cases, Ebstein-Barr virus infection. ${ }^{[6]}$ EBV can examine HFS due to cellular cytotoxicity as well as other diseases. ${ }^{[7]}$ HFS starts with fever, which may be of concern to many systems. Fever and hepatosplenomegaly are major findings. Lymphadenopathy, icterus, edema, ascites, convulsions, PRES, and cranial nerve paralysis are less common findings. As laboratory findings, anemia and thrombocytopenia develop in the early period, leukocyte count is high in some of the cases in the acute period, and neutropenia develops in some. While triglyceride, ferritin, transaminases, direct bilirubin and lactate dehydrogenase values are high, fibrinogen level is found to be low. Demonstration of hemophagocytosis in bone marrow aspiration helps in diagnosis. ${ }^{[7]} \mathrm{HLH}-2004$ diagnostic criteria are used in HFS (Table 2). In our study, HFS was shown to be most frequently associated with hematological malignancies in its etiology in adults. ${ }^{[8]}$ In our case, the absence of a familial hematological disease suggested that the patient was adult, and the detected HFS may be secondary. However, the causes that may lead to secondary HFS were investigated and HFS Its etiology has not been clarified. It is recommended to initiate chemotherapy against overactivated lymphocytes and macrophages in patients who are not immunosuppressed or in whom no underlying infectious agent has been detected. Etoposide and dexamethasone, which are toxic to macrophages, have been reported to be effective in the treatment. ${ }^{[9]}$ Other treatment options are intravenous immunoglobulin, colony stimulating factor, plasmapheresis, and bone marrow transplantation in immunocompromised cases for whom an underlying infectious agent was not detected.

\section{CONCLUSION}

While bile duct pathologies are observed most frequently in the etiology of direct hyperbilirubinemia, infiltrative diseases should be kept in mind. The first step in determining the treatment method is to determine the etiology. Bone marrow transplantation has a great place in cases caused by genetic factors. 3-year survival in cases with stem cell transplantation is $64 \%$. In cases where the etiology cannot be clarified despite early diagnosis, cases may be mortal when the treatments given by specialist physicians are insufficient.

\section{ETHICAL CONSIDERATIONS}

Informed Consent: Written informed consent was obtained from all participants who participated in this study.

Status of Peer-review: Externally peer-reviewed.

Conflict of Interest Statement: The authors have no conflicts of interest to declare.

Financial Disclosure: The authors declared that this study has received no financial support.

Author Contributions: All of the authors declare that they have all participated in the design, execution, and analysis of the paper, and that they have approved the final version.

\section{REFERENCES}

1. Pachlopnik Schmid J, Côte $M$, Ménager $M M$, et al. Inherited defects in lymphocyte cytotoxic activity. Immunol Rev 2010;235:10.

2. Filipovich A, McClain K, Grom A. Histiocytic disorders:recent insights into pathophysiology and practical guidelines. Pediatric BMT 2010;16:82-9.

3. Doğan V, Karaaslan E, Özer S, Gümüşer R, Yılmaz R. Hemophagocytosis in the Acute Phase of Fatal Kawasaki Disease in a 4 Month-Old Girl. Balkan Med J 2016;33:470-2.

4. Zur Stadt U, Beutel K, Kolberg S, et al. Mutation spectrum in children with primary hemophagocytic lymphohistiocytosis:molecular and functional analyses of PRF1, UNC13D, STX11, and RAB27A. Rheumatology 2008;47:1686-91. 
5. Fukaya S, Yasuda S, Hashimoto T, et al. Clinical features of haemophagocytic syndrome in patients with systemic autoimmune diseases:analysis of 30 cases. Rheumatology (Oxford) 2008;47(11):168691.

6. Gritta J, Shinsaku I, Goran El, et al. Infection- and malignancy-associated hemophagocytic syndromes. Hematol Oncol Clin North Am 1998;12:435.

7. Jordan MB, Allen CE, Weitzman S, Filipovich AH, McClain KL. How I treat hemophagocytic lymphohistiocytosis. Blood 2011;118(15):4041.

8. Nikiforow $\mathrm{S}$, Berliner N. The unique aspects of presentation and diagnosis of hemophagocytic lymphohistiocytosis in adults. Hematology Am Soc Hematol Educ Program 2015;2015:183

9. Henter J, Aricò M, Elinder G, Imashuku S, Janka G. Familial hemophagocytic lymphohistiocytosis. Primary hemophagocytic lymphohistiocytosis. Hematol Oncol Clin North Am 1998;12(2):417-33. 